\title{
Sodium trimetaphosphate and hexametaphosphate impregnated with silver nanoparticles: characteristics and antimicrobial efficacy
}

Carla Corrêa Mendes-Gouvêa, Jackeline Gallo do Amaral, Renan Aparecido Fernandes, Gabriela Lopes Fernandes, Luiz Fernando Gorup, Emerson Rodrigues Camargo, Alberto Carlos Botazzo Delbem \& Debora Barros Barbosa

To cite this article: Carla Corrêa Mendes-Gouvêa, Jackeline Gallo do Amaral, Renan Aparecido Fernandes, Gabriela Lopes Fernandes, Luiz Fernando Gorup, Emerson Rodrigues Camargo, Alberto Carlos Botazzo Delbem \& Debora Barros Barbosa (2018) Sodium trimetaphosphate and hexametaphosphate impregnated with silver nanoparticles: characteristics and antimicrobial efficacy, Biofouling, 34:3, 299-308, DOI: 10.1080/08927014.2018.1437146

To link to this article: https://doi.org/10.1080/08927014.2018.1437146

Published online: 27 Feb 2018.

Submit your article to this journal 준

Lll Article views: 107

View Crossmark data ‘ 


\title{
Sodium trimetaphosphate and hexametaphosphate impregnated with silver nanoparticles: characteristics and antimicrobial efficacy
}

\author{
Carla Corrêa Mendes-Gouvêa ${ }^{a}$, Jackeline Gallo do Amaral ${ }^{\mathrm{a}}$, Renan Aparecido Fernandes ${ }^{\mathrm{b}}$, \\ Gabriela Lopes Fernandes ${ }^{b}$, Luiz Fernando Gorupc, Emerson Rodrigues Camargo ${ }^{c}$ (D), \\ Alberto Carlos Botazzo Delbem ${ }^{a}$ (iD) and Debora Barros Barbosa ${ }^{b}$
}

aDepartment of Pediatric Dentistry and Public Health, School of Dentistry Araçatuba, São Paulo State University (UNESP), Araçatuba, Brazil; ${ }^{b}$ Department of Dental Materials and Prosthodontics, School of Dentistry Araçatuba, São Paulo State University (UNESP), Araçatuba, Brazil; 'Department of Chemistry, Federal University of São Carlos (UFSCar), São Carlos, Brazil

\section{ABSTRACT}

This study aimed to synthesize and characterize materials containing silver nanoparticles (AgNP) with polyphosphates (sodium trimetaphosphate (TMP) or sodium hexametaphosphate (HMP), and evaluate their effect against Candida albicans and Streptococcus mutans. The minimum inhibitory concentration (MIC) was determined, which was followed by the quantification of the biofilm by counting colony-forming units (CFUs), the amount of metabolic activity, and the total biomass. The MICs revealed greater effectiveness of composites containing 10\% Ag (TMP + Ag10\% (T10) and $\mathrm{HMP}+\mathrm{Ag} 10 \%(\mathrm{H} 10))$ against both microorganisms. It was observed that $\mathrm{T} 10$ and $\mathrm{H} 10$ reduced the formation of biofilms by $56-76 \%$ for C. albicans and by $52-94 \%$ for S. mutans for total biomass and metabolic activity. These composites promoted significant log reductions in the number of CFUs, between $0.45-1.43 \log _{10}$ for $C$. albicans and $2.88-3.71 \log _{10}$ for $S$. mutans $(p<.001)$. These composites demonstrated significant antimicrobial activity, especially against $S$. mutans, and may be considered a potential alternative for new dental materials.
ARTICLE HISTORY

Received 15 August 2017

Accepted 31 January 2018

\section{KEYWORDS}

Polyphosphates; silver nanoparticles; biofilm; Candida albicans: Streptococcus mutans

\section{Introduction}

Streptococcus mutans is the main cariogenic microorganism, and its capacity to produce acid and survive at low $\mathrm{pH}$, as well as its ability to synthesize extracellular polysaccharides, are important virulence factors which contribute to the colonization of the tooth surface, development of pathogenic biofilms, and enamel demineralization (Leone et al. 2008, Li and Chang 2008; Delbem et al. 2014). Although the development of dental caries is related to the formation of biofilm, the progression of established lesions may include species of Candida, particularly Candida albicans (Shibata and Morioka 1982; Monteiro et al. 2015).

Composites containing calcium and phosphate have shown promising anticariostatic effects (do Amaral et al. 2013; Takeshita et al. 2015; da Camara et al. 2016). Among the phosphate salts, sodium trimetaphosphate (TMP) and sodium hexametaphosphate (HMP) have been effective in reducing enamel demineralization and improving remineralization. They are inorganic cyclophosphates with the capacity to adsorb hydroxyapatite and protein through hydroxyl (Souza et al. 2013; Delbem et al. 2014) and amino (Leone et al. 2008; Li and Chang 2008) attachment sites. Added to low concentrations of fluoride in an appropriate proportion in oral health products, they provide a greater protective effect than conventional fluoride products (da Camara et al. 2014; Manarelli et al. 2015; Takeshita et al. 2015; Conceicao et al. 2015; da Camara et al. 2016).

The development of multifunctional biomaterials to be used in the health field is the focus of increasing attention. Added to that, the exponential growth of nanotechnology, and the use of silver nanoparticles (AgNP) as an antimicrobial agent allowing for increased surface-to-volume ratios and specific interactions with species of bacteria and fungi (Baker et al. 2005, Morones et al. 2005; Lok et al. 2006), new approaches could be useful to prevent and control dental caries. A material containing AgNP as an antimicrobial agent, and sources of fluoride and phosphate to prevent the demineralization of dental enamel, could achieve promising results. Thus, this study aimed to synthesize composites containing AgNP, F, and TMP or HMP, and to characterize and evaluate their effect against Streptococcus mutans and Candida albicans.

CONTACT Debora Barros Barbosa debora@foa.unesp.com

This article was originally published with errors. This version has been corrected. Please see Corrigendum (https://doi.org/10.1080/08927014.2018.1471022) 


\section{Materials and methods}

\section{Synthesis and characterization of the nanocomposites}

Nanocomposites were synthesized based on the protocol proposed by Miranda et al. (2010), with some modifications. The synthesis was carried out in an alcoholic medium (isopropanol) using sodium borohydride $\left(\mathrm{NaBH}_{4}\right.$, Sigma-Aldrich, St Louis, MO, USA) as a reducing agent. Suspensions containing sodium trimetaphosphate (TMP, Sigma-Aldrich, CAS 7785-84-4) or sodium hexametaphosphate (HMP, Sigma-Aldrich, CAS 68915-31-1), fluoride (NaF, Merck, Darmstadt, Germany), and silver nitrate $\left(\mathrm{AgNO}_{3}\right.$, Merck) were prepared in the presence of a surfactant (ammonium salt of polymethacrylic acid (NH$\mathrm{PM}$ ), Polysciences, Inc., Warrington, PA, USA). $\mathrm{AgNO}_{3}$ was employed at $1 \%$ or $10 \%$ of the phosphate weight. The molar proportions between phosphates and fluoride was 1.2:1 TMP/NaF or 0.62:1 HMP/NaF, and between silver ions $\left(\mathrm{Ag}^{+}\right)$and $\mathrm{NaBH}_{4}$ it was 1:1.26. Samples were dried overnight at $70^{\circ} \mathrm{C}$. AgNP with no polyphosphates was also synthesized.

The morphology of the nanocomposites was characterized by scanning electron microscopy (SEM) on a Zeiss Supra 35VP microscope (S-360 microscope, Leo, MA, USA) with field emission gun electron effect (FEG-SEM, $10 \mathrm{kV}$ ). A drop of each sample was placed on a silicon substratum and dried at $40^{\circ} \mathrm{C}$ for $12 \mathrm{~h}$. Two-dimensional images were constructed by analyzing the $\mathrm{P} \mathrm{Ka}, \mathrm{Ag} \mathrm{Lal}$, and $\mathrm{O}$ Ka energy emissions using energy dispersive $\mathrm{X}$-ray detector (EDX) analysis with mapping. Samples were also characterized by X-ray diffraction (XRD) (Rigaku diffractometer [Rigaku Corporation, Tokyo, Japan], DMax $2500 \mathrm{PC})$ with CuK radiation $(\lambda=1.5406 \AA)$ generated at a voltage of $40 \mathrm{kV}$ and a current of $40 \mathrm{~mA}$. The scanning range (20) was from $20^{\circ}$ to $110^{\circ}$ with a step size of $0.2^{\circ}$, a $1.0 \mathrm{~mm}$ divergent slit, $0.2 \mathrm{~mm}$ collection slot, and accumulation for reading every $0.02 \mathrm{~s}$.

\section{Determination of $\mathrm{Ag}^{+}$concentration}

The concentration of $\mathrm{Ag}^{+}$in the composites was determined by a 9616 BNWP (Thermo Scientific, Beverly, MA, USA) ion-specific electrode coupled to an ion analyzer (Orion $720 \mathrm{~A}^{+}$, Thermo Scientific). One thousand $\mu \mathrm{g}$ $\mathrm{Ag} \mathrm{ml}{ }^{-1}$ were prepared (1.57 $\mathrm{g}$ of dried $\mathrm{AgNO}_{3}$ for $1 \mathrm{lof}$ deionized water) as a standard, and diluted in deionized water to achieve equivalent silver concentrations in the composites. Thus, the combined electrode was calibrated with solutions containing 6.25 to $100 \mu \mathrm{g} \mathrm{Ag} \mathrm{ml}{ }^{-1}$. A silver ionic strength adjuster solution (ISA, Cat. No. 940011), which provides a constant background ionic strength was used ( $1 \mathrm{ml}$ of each sample/standard: $0.02 \mathrm{ml}$ of ISA).

\section{Minimum inhibitory concentration (MIC)}

The microdilution method was performed following the Clinical Laboratory Standards Institute guidelines (CLSI: M27-A2 and M07-A9). The nanocomposites were diluted in deionized water in geometric progression, from 2 to 1,024 times. Afterwards, each nanocomposite concentration obtained previously was diluted (1:5) in RPMI 1640 medium (Sigma-Aldrich) for Candida albicans (ATCC 10231), and in brain heart infusion (BHI, Difco, Le Pont de Claix, France) for Streptococcus mutans (ATCC 25175). Inocula from 24 -h cultures were adjusted to the $0.5 \mathrm{McF}$ arland standard turbidity equivalent in saline solution $(0.85 \% \mathrm{NaCl})$. Suspensions of each strain were diluted (1:5) in saline and subsequently diluted (1:20) in RPMI 1640 for C. albicans or BHI broth for S. mutans. Each microorganism suspension (100 $\mu \mathrm{l})$ was added in the wells of microtiter plates containing $100 \mu \mathrm{l}$ of each nanocomposite concentration. Polyphosphate/fluoride, AgNP, and chlorhexidine gluconate (CHG) (Periogard-Colgate, New York, NY, USA) were tested as controls. The microtiter plates were incubated at $37^{\circ} \mathrm{C}$, and the MICs were determined visually as the lowest concentration of nanocomposites with no microorganism growth after $48 \mathrm{~h}$.

\section{Biofilm formation and treatment}

Single species biofilms were grown in 96-well microtiter plates (Costar ${ }^{\oplus}$, Corning Incorporated, Tewksbury, MA, USA) containing $0.2 \mathrm{ml}$ of $C$. albicans cell suspension $\left(1 \times 10^{7}\right.$ cells ml ${ }^{-1}$ in artificial saliva) (Silva et al. 2010) or $0.2 \mathrm{ml}$ of $S$. mutans $\left(1 \times 10^{8}\right.$ cells $\mathrm{ml}^{-1}$ in artificial saliva $)$ (Arias et al. 2016). The plates were incubated at $37^{\circ} \mathrm{C}$ for $24 \mathrm{~h}$. After this period, the biofilm-containing wells were washed with $0.2 \mathrm{ml}$ of phosphate buffered saline (PBS; $\mathrm{pH} 7,0.1 \mathrm{M}$ ) to remove the non-adherent cells. Next, the nanocomposites were added to the biofilms at concentrations based on the MIC values obtained previously. For this, $0.2 \mathrm{ml}$ of the $\mathrm{T} 10$ and $\mathrm{H} 10$ nanocomposites at MIC and $10 \times$ MIC were diluted in artificial saliva, which was added to the biofilm-containing wells. AgNP with no phosphates and $\mathrm{CHG}$ at $0.018 \%$ (positive control) were also tested against the biofilms, and artificial saliva with no nanocomposites was used as negative control. The biofilms were then re-incubated at $37^{\circ} \mathrm{C}$ for $24 \mathrm{~h}$.

\section{Biofilm quantification}

The quantification of $C$. albicans and $S$. mutans cultivable cells from biofilms treated with $\mathrm{T} 10$ and $\mathrm{H} 10$ was carried out by counting colony-forming units (CFUs). For this, the biofilm-containing wells were scraped with a tip, using $0.2 \mathrm{ml}$ of PBS each time five times, totaling $1 \mathrm{ml}$ of 
suspension, and the cell suspensions were then placed in Falcon tubes. The suspensions were vortexed and serially diluted in PBS and plated on SDA (C. albicans) or BHI ( $S$. mutans). After incubation at $37^{\circ} \mathrm{C}$ for $24 \mathrm{~h}$ for C. albicans and $48 \mathrm{~h}$ for S. mutans, the total number of CFUs was counted and the $\log$ CFU per unit area $\left(\log _{10} \mathrm{CFU} \mathrm{cm}{ }^{-2}\right)$ was determined.

After the biofilms were treated, the total biomass was analyzed by the crystal violet (CV) method (Monteiro et al. 2015). The biofilms were washed with $0.2 \mathrm{ml}$ of PBS and fixed by adding $0.2 \mathrm{ml}$ of $99 \%$ methanol (SigmaAldrich) for $15 \mathrm{~min}$. The methanol was then removed and the wells were allowed to dry at room temperature. Then, $0.2 \mathrm{ml}$ of CV (1\%, $\mathrm{v} \mathrm{v}^{-1}$, Merck) were added into each well, and after $5 \mathrm{~min}$, the excess was withdrawn by washing each well-plate with deionized water. CV bound to the biofilms was eluted using $0.2 \mathrm{ml}$ of acetic acid (33\%, $\mathrm{v} \mathrm{v}^{-1}$, Sigma-Aldrich), and the absorbance was measured in a microtiter-plate reader (Eon Microplate Spectrophotometer; Bio Tek, Winooski, VT, USA) at $570 \mathrm{~nm}$, and standardized in relation to the area of the well-plate (Abs $570 \mathrm{~nm} \mathrm{~cm}^{-2}$ ).

Metabolic activity was assessed by the XTT reduction assay (2,3-bis (2-methoxy-4-nitro-5-sulfophenyl)-5[(phenylamino) carbonyl $]-2 \mathrm{H}$-tetrazolium hydroxide (Sigma-Aldrich). Biofilm-containing wells were washed once with $0.2 \mathrm{ml}$ of PBS and $0.2 \mathrm{ml}$ of the solution containing $150 \mathrm{mg} \mathrm{XTT}^{-1}$ and $10 \mathrm{mg}$ of phenazine methosulfate $1^{-1}$ in each well. The plates were then incubated at $37^{\circ} \mathrm{C}$, under agitation at $120 \mathrm{rpm}$, in the dark. After $3 \mathrm{~h}$, the absorbance was read at $490 \mathrm{~nm} \mathrm{~cm}^{-2}$. All assays were performed, independently and in triplicate, on three different occasions.

\section{Microscopy}

The structural analysis of single biofilms of C. albicans and $S$. mutans exposed to the nanocomposites was verified by SEM. Briefly, the biofilms were formed in 24-well plates as described before. Then, the T10 and H10 nanocomposites were added to the wells at the concentration of $10 / 100 \mu \mathrm{g} \mathrm{Ag} \mathrm{ml}^{-1}$ for C. albicans and $40 / 400 \mu \mathrm{g} \mathrm{Ag}$ $\mathrm{ml}^{-1}$ for $S$. mutans biofilms. After treatment for $24 \mathrm{~h}$, the wells were washed with PBS and the biofilms were dehydrated using an ethanol concentration series (70\% for $10 \mathrm{~min}$, $95 \%$ for $10 \mathrm{~min}$, and $100 \%$ for $20 \mathrm{~min}$ ), followed by air drying for $20 \mathrm{~min}$ (Silva et al. 2013). The bottom of the wells were cut with a scalpel blade (number 11, Solidor, Lamedid Commercial and Services Ltda, Barueri, Brazil) heated in flame, and the biofilms were coated with gold for scanning with the electron microscope (S-360 microscope, Leo, Cambridge, MA, USA) (Fernandes et al. 2016).

\section{Statistical analysis}

SigmaPlot 12.0 software (Systat Software Inc., San Jose, CA, USA) was used for statistical analysis; the significance level was set at 5\%. CFUs, CV (for both microorganisms tested), and XTT (C. albicans) data exhibited a normal and homogeneous distribution (Shapiro-Wilks test) and were submitted to one-way analysis of variance, followed by the Fisher test. XTT data from S. mutans were submitted to logarithmic transformation and one-way analysis of variance followed by the Fisher test.

\section{Results}

Synthesis, characterization, and $\mathbf{A g}^{+}$determination in the nanocomposites

XRD and SEM demonstrated the association of silver nanoparticles in both polyphosphates (sodium trimetaphosphate (TMP) and sodium hexametaphosphate (HMP)). The typical XRD pattern of the prepared T1 (TMP+Ag1\%) and T10 (TMP+Ag10\%) powder showed diffraction peaks at $2 \theta=14.4^{\circ}, 17.3^{\circ}, 23.4^{\circ}, 26.1^{\circ}$, and $29.2^{\circ}$, and the corresponding crystallographic form (PDF № 72-1628) of the TMP salt (Figure 1a). Figure 1a shows diffraction peaks at $2 \theta=38.2^{\circ}, 44.4^{\circ}$, and $64.6^{\circ}$, which can be indexed to (200), (111), and (220) planes of pure silver with the face-centered cubic system (PDF № 04-0783). Figure $1 \mathrm{~b}$ shows the $\mathrm{X}$-ray diffraction patterns of HMP that present a wide halo between $15^{\circ}$ and $35^{\circ}$, characteristic of amorphous materials. The X-ray diffraction patterns of $\mathrm{H} 1$ (HMP+Ag1\%) and $\mathrm{H} 10$ $(\mathrm{HMP}+\mathrm{Ag} 10 \%)$ indicate sodium hexametaphosphate salt - $\left(\mathrm{NaPO}_{3}\right)_{6}$ (PDF № 3643), and suggest the presence of other polyphosphate salts, such as $\left(\mathrm{NaH}_{2} \mathrm{PO}_{4}\right.$. $\left(\mathrm{H}_{2} \mathrm{O}\right), \mathrm{NaH}_{2} \mathrm{PO}_{4}, \mathrm{Na}_{5} \mathrm{P}_{3} \mathrm{O}_{10}, \mathrm{NaPO}_{3}$, and $\mathrm{Na}_{2} \mathrm{H}_{2} \mathrm{P}_{2} \mathrm{O}_{7}$, by comparing the experimentally obtained XRD patterns with standard patterns (PDF № 11-651, 11-659, 11-652, 76-788, and 11-657). SEM images of T10 and H10 (Figure 2) show silver nanoparticles (white shades) dispersed and decorating the surface of the phosphates at micrometric size (gray shades). AgNP anchored on the surface of HMP or TMP were more evident in samples containing $\mathrm{Ag}$ at $10 \%$ than at $1 \%$ of $\mathrm{Ag}$. The 2 -D images were constructed by analyzing the energy released from the $\mathrm{O} \mathrm{Ka}, \mathrm{P} \mathrm{Ka}$ (constituents of the TMP and HMP material) and $\mathrm{Ag} \mathrm{Ka}$ emissions, indicating the uniform distribution of these elements in the demarcated area in the micrograph.

The total amount of $\mathrm{Ag}^{+}$(from the $\mathrm{AgNO}_{3}$ source) added to the reaction to obtain AgNP with no TMP or HMP was 20,000 $\mu \mathrm{g} \mathrm{Ag} \mathrm{ml}^{-1}$, and the ionic concentration was determined by electrode method at $576.19 \mu \mathrm{g}$ $\mathrm{Ag} \mathrm{ml}{ }^{-1}$, thus a reduction of $97.12 \%$ of ionic silver was 
(a)

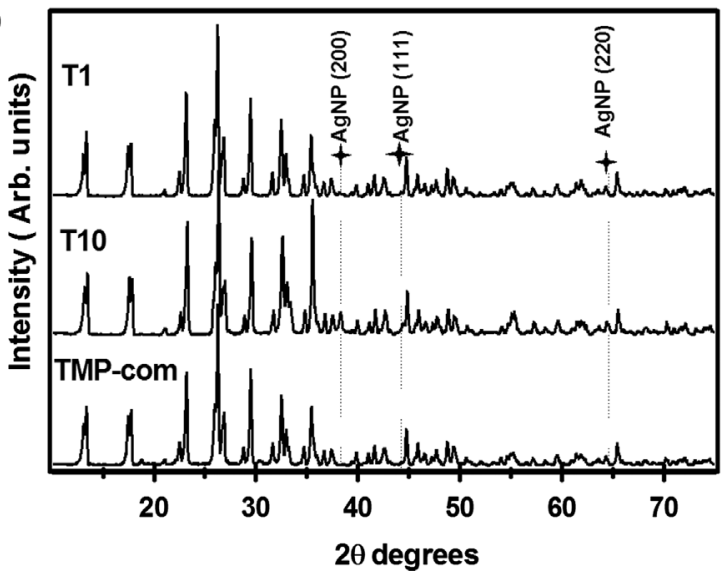

(b)

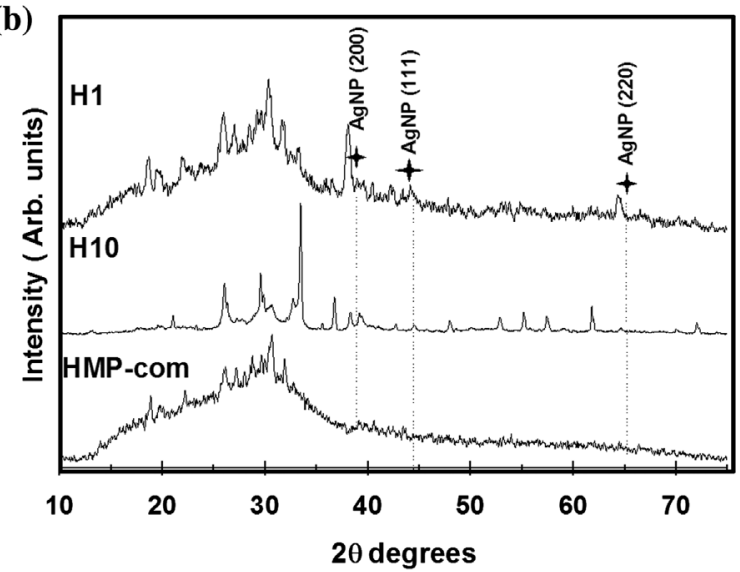

Figure 1. XRD patterns of commercial TMP (a) and HMP powder (b) and the synthesized nanocomposites, respectively.

(a)
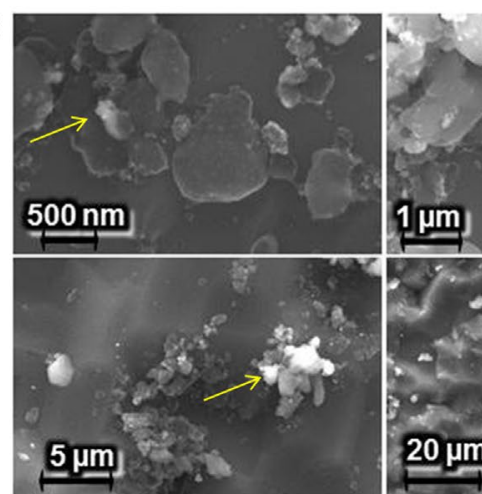

(b)
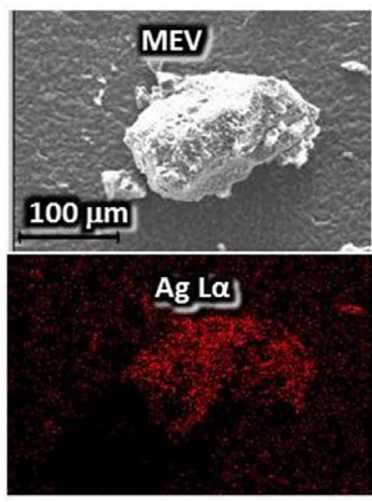
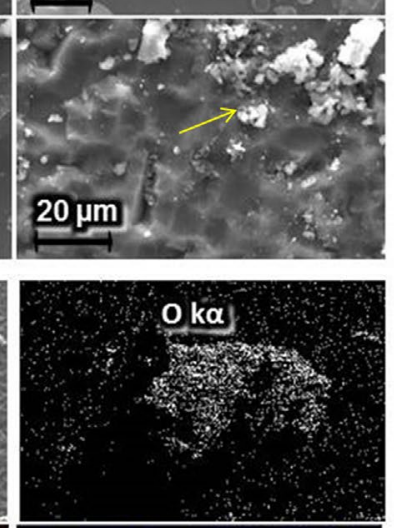

$\mathbf{P}_{\underline{\alpha}}$ (c)

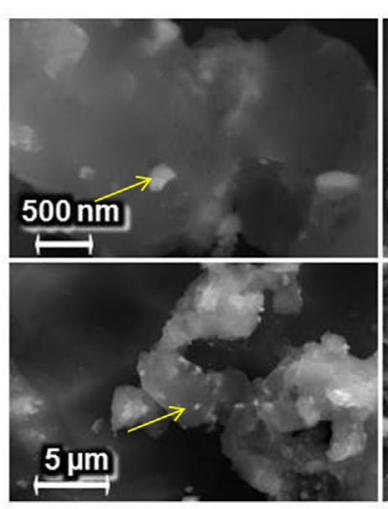

(d)

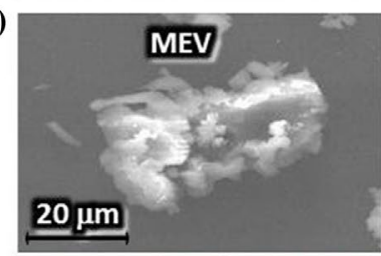

Ag $L \alpha$
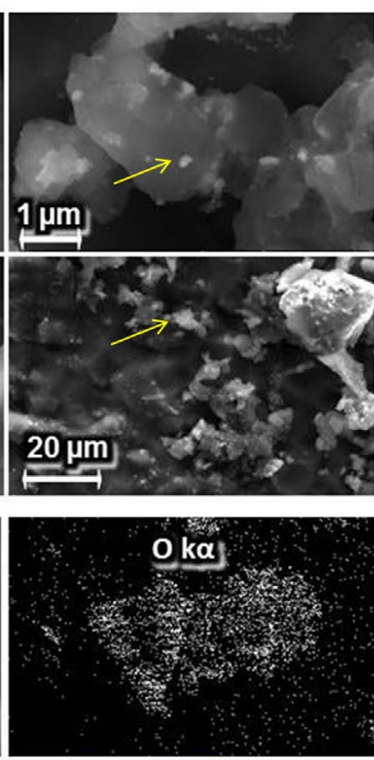

$P \underline{k}_{\underline{\alpha}}$

Figure 2. SEM images and EDX mapping in 2-D at different magnifications of T10 ( $a$ and b) and H10 (c and d). Arrows indicate AgNP dispersed on TMP and HMP surfaces. Red dots show silver distribution on phosphates.

observed. All samples containing Ag at 1\% (H1 and $\mathrm{T} 1$ ) or $10 \%$ (H10 and $\mathrm{T} 10)$ presented $\mathrm{Ag}^{+} \%$ reduction between 98.04 and $99.85 \%$. For $\mathrm{H} 1$ and $\mathrm{T} 1$ samples, the $\mathrm{Ag}$ concentrations were determined as 1.43 and $8.13 \mu \mathrm{g}$ $\mathrm{Ag}^{+} \mathrm{ml}^{-1}$, and the total amount of $\mathrm{Ag}$ used in the reaction was $1,000 \mu \mathrm{g} \mathrm{Ag} \mathrm{ml}^{-1}$. For $\mathrm{H} 10$ and T10 samples, the Ag concentrations were 129.8 and $195.4 \mu \mathrm{g} \mathrm{Ag} \mathrm{ml}^{-1}$, and the total amount of $\mathrm{Ag}$ used in the reaction was $10,000 \mu \mathrm{g}$ $\mathrm{Ag} \mathrm{ml^{-1 }}$.

\section{Antimicrobial effect}

The nanocomposites were effective against both strains tested in planktonic form (Table 1). Composites containing $\mathrm{Ag}$ at $10 \%$ (T10 and $\mathrm{H} 10$ ) were more effective against C. albicans $(10 \mu \mathrm{g} \mathrm{Ag} \mathrm{V)}$ than against S. mutans $(40 \mu \mathrm{g} \mathrm{Ag}$ $\mathrm{V})$, while at $1 \% \mathrm{Ag}$ only $\mathrm{H} 1$ presented an effect against the microorganisms $(80 \mu \mathrm{g} \mathrm{Ag} \mathrm{V})$. For the group of AgNP without TMP or HMP synthesized in the same conditions, 
Table 1. MIC values of each composite and the controls tested against the two microorganisms.

\begin{tabular}{lcc}
\hline & \multicolumn{2}{c}{ MIC $\left(\mu \mathrm{g} \mathrm{Ag} \mathrm{m}^{-1}\right)$} \\
\cline { 2 - 3 } Composites and controls & Streptococcus mutans & Candida albicans \\
\hline T1 & - & - \\
T10 & 40 & 10 \\
H1 & 80 & 80 \\
$\mathrm{H} 10$ & 40 & 10 \\
AgNP & 125 & 62.5 \\
CHG & 0.93 & 3.75 \\
F & 125 & - \\
TMP & - & - \\
HMP & 6.25 & 12.5 \\
AgNO $_{3}$ & 12.5 & 3.15 \\
\hline
\end{tabular}

the MIC values were $62.5 \mu \mathrm{g} \mathrm{Ag} \mathrm{ml}{ }^{-1}$ for $C$. albicans and $125 \mu \mathrm{g} \mathrm{Ag} \mathrm{ml}{ }^{-1}$ for S. mutans. At lower Ag concentration (1\%), only $\mathrm{H} 1$ presented a antimicrobial effect.

In this study, biofilm cells of $C$. albicans were resistant to all concentrations tested of AgNP without phosphates (Figure 3). However, after adding the polyphosphates to the AgNP, there were significant reductions of $1.43 \log _{10}$ in the C. albicans biofilm treated with T10, and $1.17 \log _{10}$ treated with $\mathrm{H} 10\left(100 \mu \mathrm{g} \mathrm{Ag} \mathrm{ml}^{-1}\right)$ (Figure 3a), when compared to the negative control group $(p=0.004$ and $p=$ 0.014). Surprisingly, $S$. mutans biofilm cells were more susceptible to $\mathrm{T} 10$ and $\mathrm{H} 10$ than the C. albicans biofilm cells, and they were similar to the CHG positive control (PC) (Figure 3a). Notably, there was a reduction of 4.2 $\log _{10}$ in the $S$. mutans biofilm at the lowest concentration $\left(40 \mu \mathrm{g} \mathrm{Ag} \mathrm{ml}^{-1}\right)$ of T10.

The total biomass quantification and metabolic activity in the C. albicans and S. mutans biofilms are shown in Figure $3 \mathrm{~b}$ and c. Significant reductions $(\sim 75 \%)$ in the total biomass of both microorganisms were observed in the lowest concentrations of $\mathrm{T} 10\left(10 \mu \mathrm{g} \mathrm{Ag} \mathrm{ml}{ }^{-1}\right)$ and $\mathrm{H} 10$ (40 $\mu \mathrm{g} \mathrm{Ag} \mathrm{ml}^{-1}$ ), being similar to CHG (PC) (Figure 3b). Notably, the metabolic activity (Figure 3c) of C. albicans biofilm was reduced (93.4-94.4\%) at both 10 and $100 \mu \mathrm{g}$ $\mathrm{Ag} \mathrm{ml}^{-1}$ of $\mathrm{T} 10$ and at $100 \mu \mathrm{g} \mathrm{Ag} \mathrm{ml}^{-1}$ of $\mathrm{H} 10$ (92.0\%). T10 and $\mathrm{H} 10$ nanocomposites reduced the metabolic activity of S. mutans biofilms by $\sim 90 \%$, at all concentrations tested.
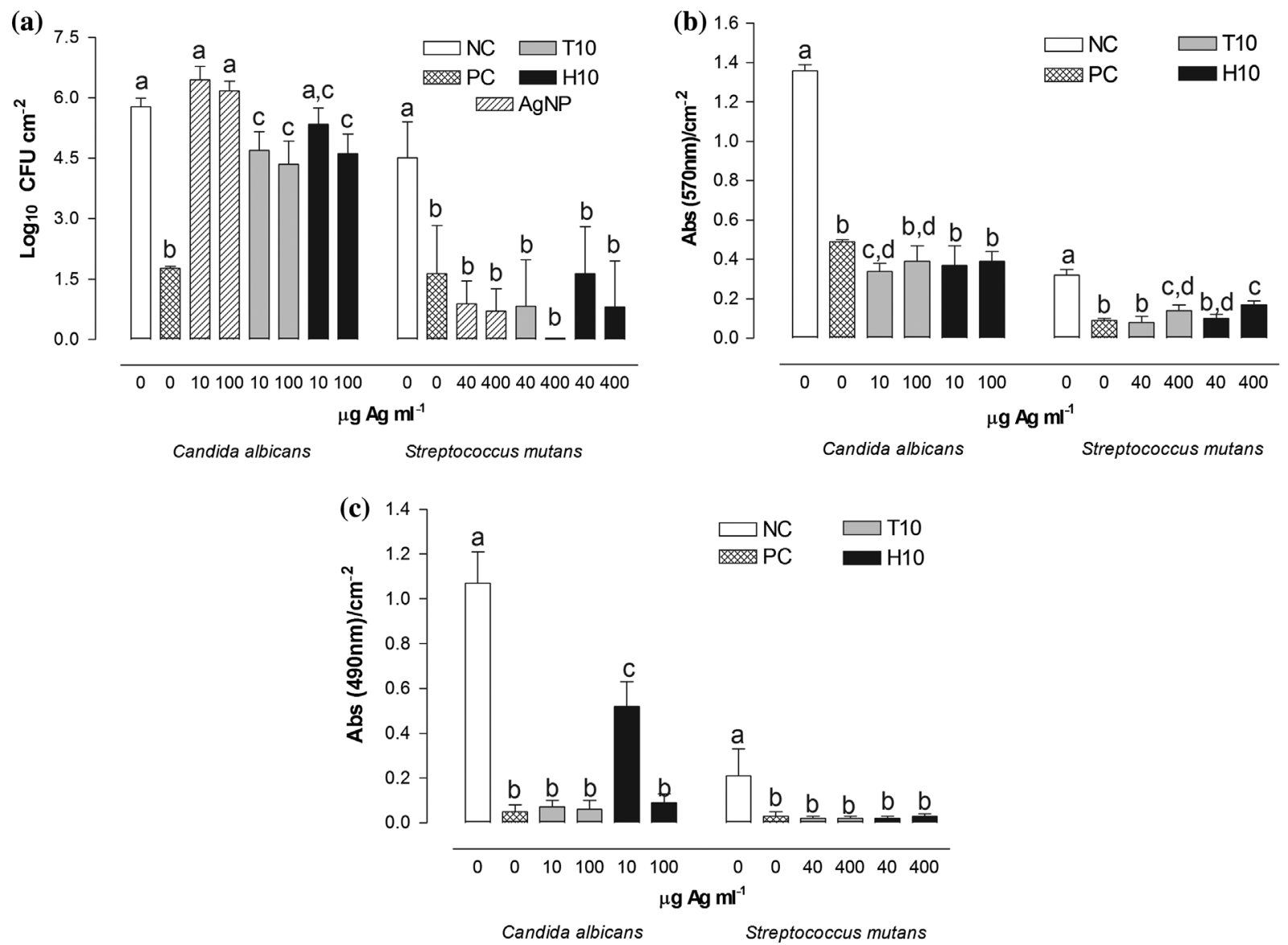

Figure 3. (a) Logarithm (mean $\pm d p$ ) of colony forming units normalized by adhesion area $\left(\log _{10} \mathrm{CFU} \mathrm{cm}^{-2}\right)$; (b) absorbance values per $\mathrm{cm}^{2}$ obtained through crystal violet assay; (c) absorbance values per $\mathrm{cm}^{2}$ obtained through XTT assay for $C$. albicans and S. mutans biofilms after treatment for $24 \mathrm{~h}$. Bars indicate SD of the mean. Different lowercase letters represent statistical difference between groups and concentrations tested (Fisher, $p<0.001$ ). NC=negative control; PC=positive control (CHG); T10=TMP-AgNP10\%; H10=HMP-AgNP10\%. 


\section{Microscopy}

Figure 4 shows hyphal cell density similar to the negative control in all C. albicans biofilms exposed to nanocomposites $\mathrm{T} 10$ and $\mathrm{H} 10$, while a reduction in cellular biomass was observed in biofilm treated with chlorhexidine gluconate. On the other hand, the quantity of cells in the S. mutans biofilms treated with $\mathrm{T} 10$ and $\mathrm{H} 10$ was as suppressed as in the biofilm subjected to chlorhexidine gluconate treatment (Figure 5).

\section{Discussion}

This study evaluated the antimicrobial action of nanocomposites against strains of $C$. albicans and $S$. mutans in both the planktonic form and in biofilms grown for $24 \mathrm{~h}$. Analyses included the quantification of viable cells, total biomass, and metabolic activity.

Currently, there are several studies in the literature that show the mechanism of action of silver nanoparticles. As has already been demonstrated, silver nanoparticles

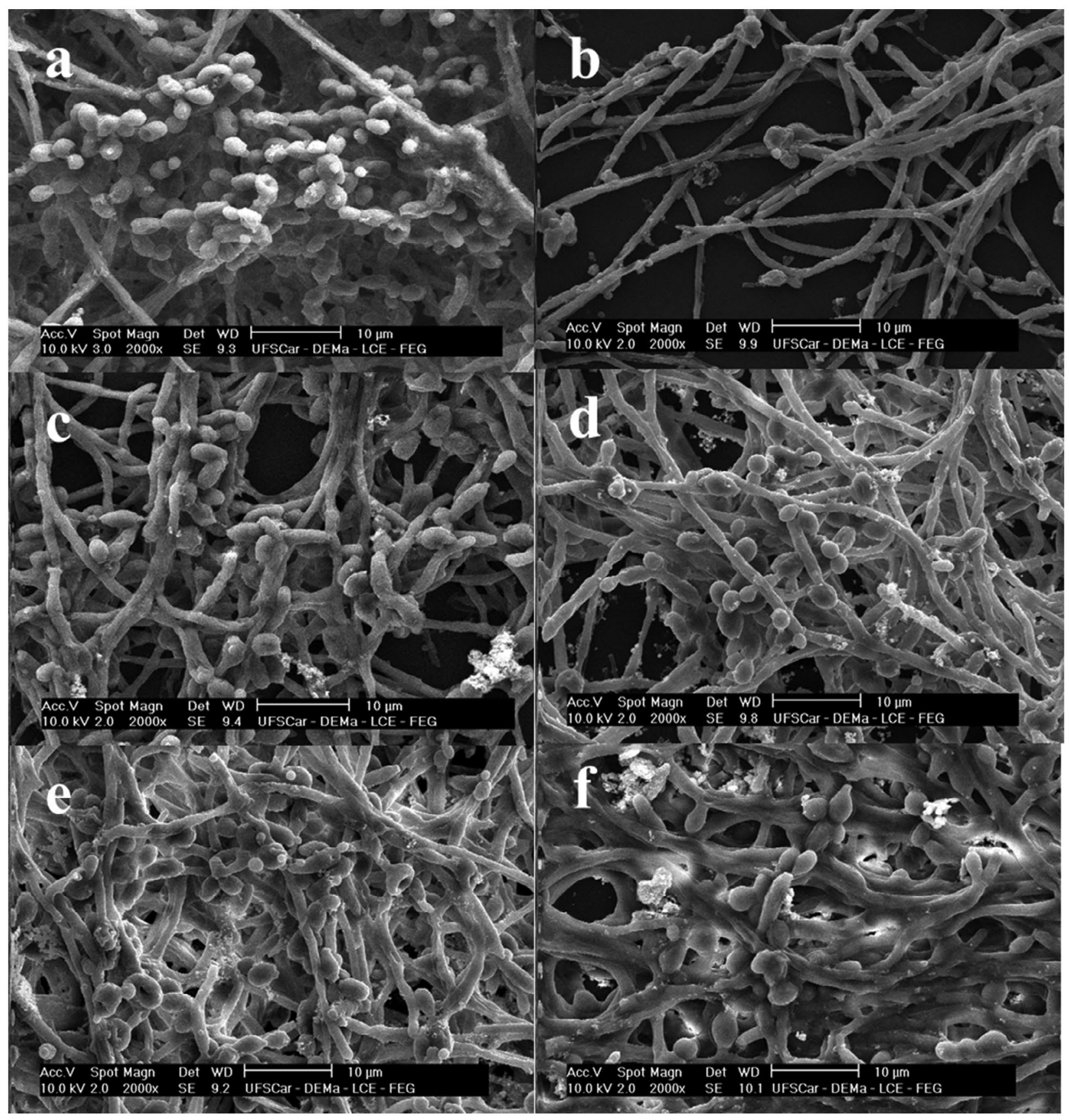

Figure 4. SEM images of C. albicans biofilms: (a) negative control; (b) positive control; (c) T10 (10 $\left.\mu \mathrm{gAg} \mathrm{ml}{ }^{-1}\right)$; (d) T10 (100 $\left.\mu \mathrm{gAg} \mathrm{ml^{-1 }}\right)$; (e) $\mathrm{H} 10\left(10 \mu \mathrm{gAg} \mathrm{ml}{ }^{-1}\right)$; (f) $\mathrm{H} 10\left(100 \mu \mathrm{gAg} \mathrm{m} l^{-1}\right)$. 


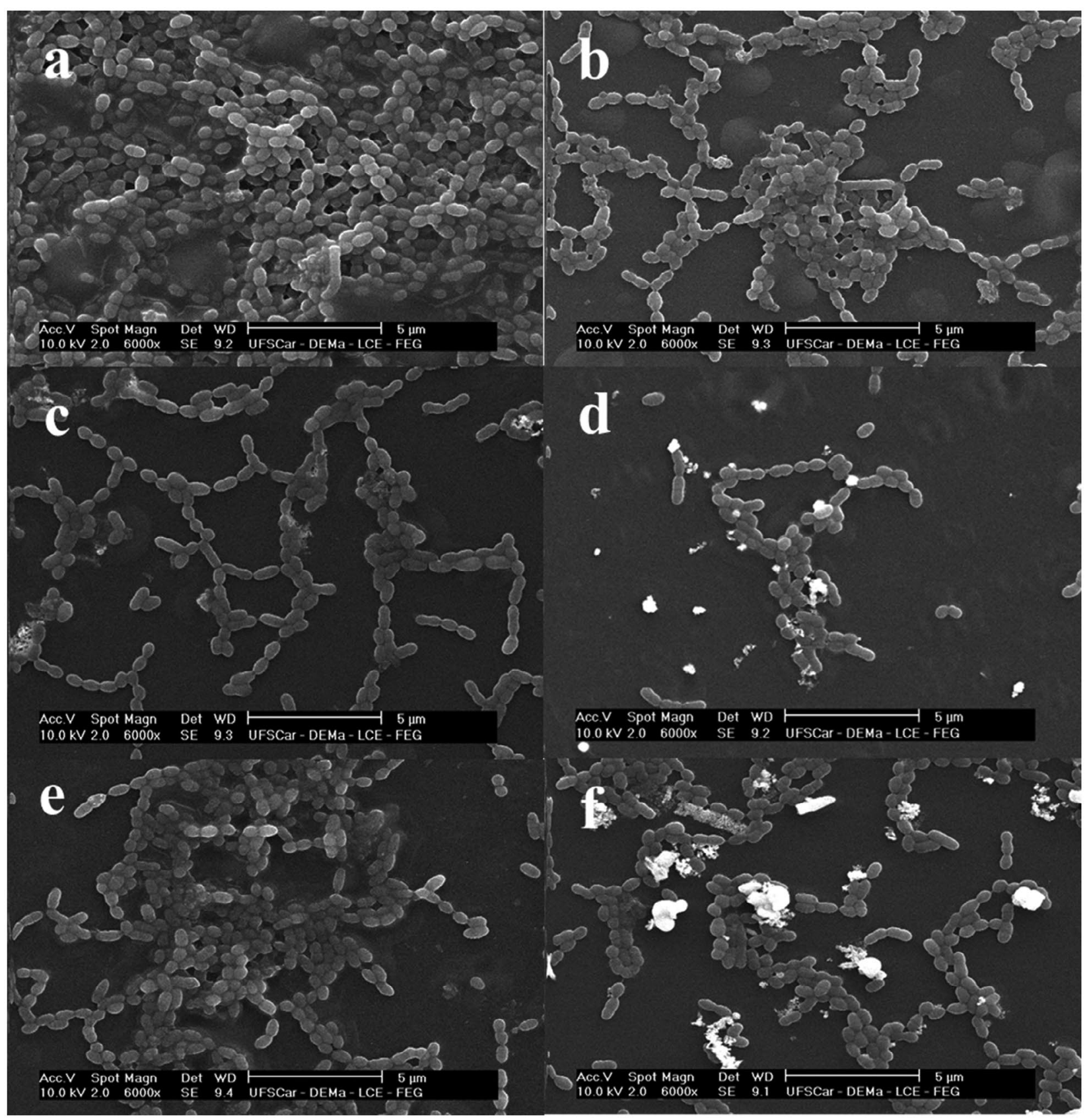

Figure 5. SEM images of S. mutans biofilms: (a) negative control; (b) positive control; (c) T10 (40 $\left.\mu \mathrm{gAg} \mathrm{ml}^{-1}\right)$; (d) $\mathrm{T} 10$ (400 $\mu \mathrm{gAg} \mathrm{ml} \mathrm{m}^{-1}$ ); (e) $\mathrm{H} 10\left(40 \mu \mathrm{gAg} \mathrm{ml}^{-1}\right)$; (f) $\mathrm{H} 10\left(400 \mu \mathrm{gAg} \mathrm{ml} l^{-1}\right)$.

promote direct damage to the cellular membrane by adhering to it (Li et al. 2008) or by dissolving it through the release of silver ions (Kon and Rai 2013). Then, once inside the cell of the microorganism, silver nanoparticles can lead to DNA damage (Li et al. 2008), mainly via production of ROS (Marambio-Jones and Hoek 2010; Duran et al. 2016), and can also affect the electrochemical proton gradient through the respiratory process, which could discontinue the ATP synthesis, leading to the death of the microorganism cell (Reidy et al. 2013).
The combination of silver nanoparticles with other compounds may improve their antimicrobial activity (Pal et al. 2007; Monteiro et al. 2013). The results of the present study demonstrated that the association of AgNP with TMP or HMP did not hinder the antimicrobial silver effect, but the association of $\mathrm{Ag}$ and polyphosphates resulted in similar MICs at a lower Ag concentration (Table 1). The crystallographic surface structures of AgNP are an important physico-chemical property which is related to their antibacterial activity (Pal et al. 2007), and could be 
changed when associated with those polyphosphates. The composites were more effective against planktonic cells of C. albicans $\left(10 \mu \mathrm{g} \mathrm{Ag} \mathrm{ml}{ }^{-1}\right)$ than S. mutans $\left(40 \mathrm{Ag} \mathrm{ml}^{-1}\right)$ when the Ag concentration was 10\% (T10 and H10), while at $1 \%$, just $\mathrm{H} 1$ showed an antimicrobial effect $(80 \mu \mathrm{g} \mathrm{Ag}$ $\mathrm{ml}^{-1}$ ). HMP has the ability to increase outer membrane cell permeability (Shibata and Morioka 1982; Vaara and Jaakkola 1989), and it might facilitate Ag entrance into the microorganism cells. Indeed, the polyphosphate property of adsorption on protein by hydroxyl and amino sites (Leone et al. 2008; Li and Chang 2008) may increase Ag availability and improve the antimicrobial effect of those composites. This was observed especially for T10 (TMP+Ag10\%) and H10, (HMP+Ag10\%) which have a higher Ag concentration impregnated on the phosphates. $\mathrm{H} 1(\mathrm{HMP}+\mathrm{Ag} 1 \%)$ alone was shown to be effective against both planktonic strains. These results demonstrate that not only was the amount of Ag relevant for the antimicrobial effectiveness of the composites, but its association with the phosphates had a significant role in the increase in the antimicrobial potential of the TMP/HMP-AgNP nanocomposites. This has also been demonstrated by Humphreys et al. (2011) and the synergism between polyphosphates and silver might increase the permeability of the outer membrane of bacteria associated to sequestration of divalent cations by polyphosphate (Maier et al. 1999; Akhtar et al. 2008; Obritsch et al. 2008), enabling silver to pass through the membrane and then causing damage to the cell, such as loss of DNA replication and protein inactivation (Feng et al. 2000).

The greater susceptibility of planktonic cells of C. albicans in comparison to S. mutans planktonic cells can be primarily explained by the structural differences in their cell membranes (Malanovic and Lohner 2016). Membranes of bacteria are negatively charged due to anionic phospholipids, while the charge in fungal membranes is neutral, constituted by zwitterionic phospholipids and ergosterol. The work of Abbaszadegan et al. (2015) states that the antimicrobial action of the nanoparticle shelf depends on the charge of the external surface of the particles as influenced by the stabilizers and capping agents used in the synthesis; thus, the AgNP fabricated in the present study can be considered negatively charged. According to Mandal et al. (2016), the mechanism of AgNP action depends on the outer charge of the bacterial membranes, and this may explain the decreased susceptibility of $S$. mutans. Furthermore, the physical and chemical properties of the AgNP related to the release of $\mathrm{Ag}^{+}$ions are noteworthy. It seemed that $\mathrm{AgNP}$ were more clearly adhered to the surface of TMP than the surface of HPM (Figure 2a and c). This could facilitate the release of $\mathrm{Ag}^{+}$ions, and hence, its highest concentration in the composites containing TMP, regardless of the amount of
$\mathrm{AgNO}_{3}(1$ or $10 \%)$ used in the synthesis reaction. On the other hand, it did not increase the antimicrobial effectiveness of the T10, suggesting antimicrobial activity is not just related to the amount of $\mathrm{Ag}^{+}$ions released from that composite.

However, many antimicrobial agents that show effectiveness against planktonic cells could be ineffective against the same microorganism grown in a biofilm (Jefferson 2004; Kim et al. 2008). Biofilms of Candida species, for example, can exhibit up to 65 times more tolerance to killing by metals than corresponding planktonic cultures (Harrison et al. 2007). Although biofilms of C. albicans showed tolerance against pure AgNP (Figure 3a), the addition of the polyphosphates resulted in inhibition of the growth of fungal biofilms. The same occurred against biofilm cells of $S$. mutans. Nevertheless, the microscopy images (Figures 4 and 5) show that growth of C. albicans biofilm cells was similar to the negative control, while the reduction in biofilm cells of $S$. mutans was consistent with chlorhexidine gluconate, as shown through CFU analysis. The explanation would also be related to the mechanism of action of polyphosphates on planktonic cells (Maier et al. 1999; Akhtar et al. 2008; Obritsch et al. 2008), and also for a probable buffer effect promoted by the phosphates in the $S$. mutans biofilm environment. To this end, as S. mutans is an acidogenic and aciduric bacterial strain, TMP and HMP may have hampered the decrease in $\mathrm{pH}$, and hence, the proliferation of the cells in the biofilm.

The total biomass and metabolic activity of fungal and bacterial biofilms are shown in Figure $3 \mathrm{~b}$ and c. Overall, the methods used to quantify microbial biofilms were performed as complementary analysis. As shown in the results, the lowest concentrations of $\mathrm{T} 10\left(10 \mu \mathrm{g} \mathrm{Ag} \mathrm{ml}{ }^{-1}\right)$ and $\mathrm{H} 10\left(40 \mu \mathrm{g} \mathrm{Ag} \mathrm{ml}^{-1}\right)$ were able to reduce the total biomass in a manner similar to the positive control (CHG). Figure $3 \mathrm{c}$ shows the reduction in biofilm activity of C. albicans of between 92 and $94.4 \%$, with the exception of the concentration of $10 \mu \mathrm{g} \mathrm{Ag} \mathrm{ml}{ }^{-1} \mathrm{H} 10$. All concentrations of both $\mathrm{T} 10$ and $\mathrm{H} 10$ reduced the biofilm biomass of $S$. mutans by $\sim 90 \%$. Nevertheless, it is noteworthy that S. mutans may not have properly absorbed and/or metabolized the salt of XTT (Kuhn et al. 2003; Gobor et al. 2011), and hence, interfered with the spectrophotometer reading since there was also low metabolic activity in the negative control group (NC).

Finally, looking at the antimicrobial effect of the polyphosphates TMP or HMP-AgNP in comparison with AgNP alone, the findings of the present study demonstrate that both TMP and HMP with a very low NaF concentration substantially improved the effectiveness of AgNP against both the planktonic and sessile forms of the microorganism. This suggests that AgNP associated with TMP or HMP polyphosphates and fluoride may be effective 
antimicrobial biomaterials for promising applications to control caries disease. Future studies should investigate the remineralization potential of these composites as well as their toxicity to make their incorporation in dental materials feasible. Studies considering different approaches to investigate the mechanisms of action of these nanocomposites would also be opportune.

\section{Conclusion}

In this study, nanocomposites formed by AgNP associated with TMP or HMP polyphosphates and very low concentrations of fluoride were synthesized. The antimicrobial and anti-biofilm effectiveness of these nanocomposites were observed against $S$. mutans and C. albicans, both relevant dental caries pathogens. Furthermore, the results suggest that TMP and HMP improved the antimicrobial potential of AgNP, enabling the use of smaller amounts of AgNP to produce more biocompatible nanomaterials, which would be effective at reducing caries -inducing pathogens and increasing the dental remineralization process.

\section{Acknowledgments}

The authors are thankful to the CAPES Foundation (Coordination for the Improvement of Higher Education Personnel, Brazil) for a PhD scholarship for the first author, and the Interdisciplinary Laboratory of Electrochemistry and Ceramics of the Chemistry Department - LIEC - UFSCar, Brazil, for synthesizing and characterizing the composites.

\section{Disclosure statement}

No potential conflict of interest was reported by the authors.

\section{Funding}

This work supported by Coordenação de Aperfeiçoamento de Pessoal de Nível Superior.

\section{ORCID}

Emerson Rodrigues Camargo (iD http://orcid.org/0000-00032893-5353

Alberto Carlos Botazzo Delbem (D) http://orcid.org/0000-0002$8159-4853$

\section{References}

Abbaszadegan A, Ghahramani Y, Gholami A, Hemmateenejad B, Dorostkar S, Nabavizadeh M, Sharghi H. 2015. The effect of charge at the surface of silver nanoparticles on antimicrobial activity against gram-positive and gram-negative bacteria: a preliminary study. J Nanomater. 2015:1-8.
Akhtar S, Paredes-Sabja D, Sarker MR. 2008. Inhibitory effects of polyphosphates on Clostridium perfringens growth, sporulation and spore outgrowth. Food Microbiol. 25:802808. doi:10.1016/j.fm.2008.04.006

do Amaral, JG, Sassaki KT, Martinhon CC, Delbem AC. 2013. Effect of low-fluoride dentifrices supplemented with calcium glycerophosphate on enamel demineralization in situ. Am J Dent. 26:75-80.

Arias LS, Delbem AC, Fernandes RA, Barbosa DB, Monteiro DR. 2016. Activity of tyrosol against single and mixedspecies oral biofilms. J Appl Microbiol. 120:1240-1249. doi:10.1111/jam.2016.120.issue-5

Baker C, Pradhan A, Pakstis L, Pochan DJ, Shah SI. 2005. Synthesis and antibacterial properties of silver nanoparticles. J Nanosci Nanotechnol. 5:244-249.

da Camara DM, Miyasaki ML, Danelon M, Sassaki KT, Delbem AC. 2014. Effect of low-fluoride toothpastes combined with hexametaphosphate on in vitro enamel demineralization. J Dent. 42:256-262. doi:10.1016/j.jdent.2013.12.002

da Camara DM, Pessan JP, Francati TM, Souza JA, Danelon M, Delbem AC. 2016. Fluoride toothpaste supplemented with sodium hexametaphosphate reduces enamel demineralization in vitro. Clin Oral Investig. 20:1981-1985. doi:10.1007/s00784-015-1707-x

Conceicao JM, Delbem AC, Danelon M, da Camara DM, Wiegand A, Pessan JP. 2015. Fluoride gel supplemented with sodium hexametaphosphate reduces enamel erosive wear in situ. J Dent. 43:1255-1260. doi:10.1016/j.jdent.2015.08.006

Delbem AC, Souza JA, Zaze AC, Takeshita EM, Sassaki KT, Moraes JC. 2014. Effect of trimetaphosphate and fluoride association on hydroxyapatite dissolution and precipitation in vitro. Braz Dent J. 25:479-484. doi:10.1590/01036440201300174

Duran N, Duran M, de Jesus MB, Seabra AB, Favaro WJ, Nakazato G. 2016. Silver nanoparticles: a new view on mechanistic aspects on antimicrobial activity. Nanomedicine. 12:789-799. doi:10.1016/j.nano.2015.11.016

Feng QL, Wu J, Chen GQ, Cui FZ, Kim TN, Kim JO. 2000. A mechanistic study of the antibacterial effect of silver ions on Escherichia coli and Staphylococcus aureus. J Biomed Mater Res. 52:662-668. doi:10.1002/(ISSN)1097-4636

Fernandes RA, Monteiro DR, Arias LS, Fernandes GL, Delbem AC, Barbosa DB. 2016. Biofilm formation by Candida albicans and Streptococcus mutans in the presence of farnesol: a quantitative evaluation. Biofouling. 32:329-338. doi:10.1080/08927014.2016.1144053

Gobor T, Corol G, Ferreira LE, Rymovicz AU, Rosa RT, Campelo PM, Rosa EA. 2011. Proposal of protocols using D-glutamine to optimize the 2,3-bis(2-methoxy-4-nitro-5sulfophenly)-5-[(phenylamino)carbonyl]-2H-tetrazolium hydroxide (XTT) assay for indirect estimation of microbial loads in biofilms of medical importance. J Microbiol Methods. 84:299-306. doi:10.1016/j.mimet.2010.12.018

Harrison JJ, Ceri H, Yerly J, Rabiei M, Hu Y, Martinuzzi R, Turner RJ. 2007. Metal ions may suppress or enhance cellular differentiation in Candida albicans and Candida tropicalis biofilms. Appl Environ Microbiol. 73:4940-4949. doi:10.1128/AEM.02711-06

Humphreys G, Lee GL, Percival SL, McBain AJ. 2011. Combinatorial activities of ionic silver and sodium hexametaphosphate against microorganisms associated 
with chronic wounds. J Antimicrob Chemother. 66:25562561. doi:10.1093/jac/dkr350

Jefferson KK. 2004. What drives bacteria to produce a biofilm? FEMS Microbiol Lett. 236:163-173. doi:10.1111/ fml.2004.236.issue-2

Kim J, Pitts B, Stewart PS, Camper A, Yoon J. 2008. Comparison of the antimicrobial effects of chlorine, silver ion, and tobramycin on biofilm. Antimicrob Agents Chemother. 52:1446-1453. doi:10.1128/AAC.00054-07

Kon K, Rai M. 2013. Metallic nanoparticles: mechanism of antibacterial action and influencing factors. J Comp Clin Pathol Res. 1:160-174.

Kuhn DM, Balkis M, Chandra J, Mukherjee PK, Ghannoum MA. 2003. Uses and limitations of the XTT assay in studies of Candida growth and metabolism. J Clin Microbiol. 41:506-508. doi:10.1128/JCM.41.1.506-508.2003

Leone G, Torricelli P, Giardino R, Barbucci R. 2008. New phosphorylated derivatives of carboxymethylcellulose with osteogenic activity. Polym Adv Technol. 19:824-830.

Li X, Chang J. 2008. Preparation of bone-like apatitecollagen nanocomposites by a biomimetic process with phosphorylated collagen. J Biomed Mater Res A. 85:293300. doi:10.1002/(ISSN)1552-4965

Li Q, Mahendra S, Lyon DY, Brunet L, Liga MV, Li D, Alvarez PJ. 2008. Antimicrobial nanomaterials for water disinfection and microbial control: potential applications and implications. Water Res. 42:4591-4602. doi:10.1016/j.watres.2008.08.015

Lok CN, Ho CM, Chen R, He QY, Yu WY, Sun H, Tam PK, Chiu JF, Che CM. 2006. Proteomic analysis of the mode of antibacterial action of silver nanoparticles. J Proteome Res. 5:916-924.

Maier SK, Scherer S, Loessner MJ. 1999. Long-chain polyphosphate causes cell lysis and inhibits Bacillus cereus septum formation, which is dependent on divalent cations. Appl Environ Microbiol. 65:3942-3949.

Malanovic N, Lohner K. 2016. Gram-positive bacterial cell envelopes: the impact on the activity of antimicrobial peptides. Biochim Biophys Acta. 1858:936-946. doi:10.1016/j.bbamem.2015.11.004

Manarelli MM, Delbem AC, Binhardi TD, Pessan JP. 2015. In situ remineralizing effect of fluoride varnishes containing sodium trimetaphosphate. Clin Oral Investig. 19:21412146. doi:10.1007/s00784-015-1492-6

Mandal D, Kumar Dash S, Das B, Chattopadhyay S, Ghosh T, Das D, Roy S. 2016. Bio-fabricated silver nanoparticles preferentially targets Gram positive depending on cell surface charge. Biomed Pharmacother. 83:548-558. doi:10.1016/j.biopha.2016.07.011

Marambio-Jones C, Hoek E. 2010. A review of the antibacterial effects of silver nanomaterials and potential implications for human health and the environment. J Nanopart Res. 12:1531-1551. doi:10.1007/s11051-010-9900-y

Miranda M, Fernández A, Diaz M, Esteban-Tejeda L, LopezEsteban S, Malpartida F, Torrecillas R, Moya JS. 2010. Silver-hydroxyapatite nanocomposites as bactericidal and fungicidal materials. Int J Mater Res. 101:122-127.
Monteiro DR, Feresin LP, Arias LS, Barao VA, Barbosa DB, Delbem AC. 2015. Effect of tyrosol on adhesion of Candida albicans and Candida glabrata to acrylic surfaces. Med Mycol. 53:656-665. doi:10.1093/mmy/myv052

Monteiro DR, Silva S, Negri M, Gorup LF, de Camargo ER, Oliveira R, Barbosa DB, Henriques M. 2013. Antifungal activity of silver nanoparticles in combination with nystatin and chlorhexidine digluconate against Candida albicans and Candida glabrata biofilms. Mycoses. 5:672-680. doi:10.1111/ myc.2013.56.issue-6

Morones JR, Elechiguerra JL, Camacho A, Holt K, Kouri JB, Ramirez JT, Yacaman MJ. 2005. The bactericidal effect of silver nanoparticles. Nanotechnology. 1:2346-2353. doi:10.1088/0957-4484/16/10/059

Obritsch JA, Ryu D, Lampila LE, Bullerman LB. 2008. Antibacterial effects of long-chain polyphosphates on selected spoilage and pathogenic bacteria. J Food Prot. 71:1401-1405. doi:10.4315/0362-028X-71.7.1401

Pal S, Tak YK, Song JM. 2007. Does the antibacterial activity of silver nanoparticles depend on the shape of the nanoparticle? A study of the Gram-negative bacterium Escherichia coli. Appl Environ Microbiol. 73:1712-1720. doi:10.1128/ AEM.02218-06

Reidy B, Haase A, Luch A, Dawson KA, Lynch I. 2013. Mechanisms of silver nanoparticle release, transformation and toxicity: a critical review of current knowledge and recommendations for future studies and applications. Materials (Basel). 6:2295-2350. doi:10.3390/ma6062295

Shibata H, Morioka T. 1982. Antibacterial action of condensed phosphates on the bacterium Streptococcus mutans and experimental caries in the hamster. Arch Oral Biol. 27:809816. doi:10.1016/0003-9969(82)90034-6

Silva S, Henriques M, Oliveira R, Williams D, Azeredo J. 2010. In vitro biofilm activity of non-Candida albicans Candida species. Curr Microbiol. 61:534-540. doi:10.1007/s00284010-9649-7

Silva S, Pires P, Monteiro DR, Negri M, Gorup LF, Camargo ER, Barbosa DB, Oliveira R, Williams DW, Henriques M, Azeredo J. 2013. The effect of silver nanoparticles and nystatin on mixed biofilms of Candida glabrata and Candida albicans on acrylic. Med Mycol. 51:178-184. doi:10.3109/13 693786.2012.700492

Souza JA, Amaral JG, Moraes JC, Sassaki KT, Delbem AC. 2013. Effect of sodium trimetaphosphate on hydroxyapatite solubility: an in vitro study. Braz Dent J. 24:235-240. doi:10.1590/0103-6440201302000

Takeshita EM, Danelon M, Castro LP, Sassaki KT, Delbem AC. 2015. Effectiveness of a toothpaste with low fluoride content combined with trimetaphosphate on dental biofilm and enamel demineralization in situ. Caries Res. 49:394-400. doi:10.1159/000381960

Vaara M, Jaakkola J. 1989. Sodium hexametaphosphate sensitizes Pseudomonas aeruginosa, several other species of Pseudomonas, and Escherichia coli to hydrophobic drugs. Antimicrob Agents Chemother. 33:1741-1747. doi:10.1128/ AAC.33.10.1741 